\title{
CORRELATION BETWEEN MICROSTRUCTURE, PHASE COMPOSITION AND MECHANICAL PROPERTIES OF THERMO-INSULATION BONDING AGENTS BASED ON WASTE MATERIAL
}

$U D C$ 699.86:620.17=111

\author{
Anja Terzić ${ }^{1 \#}$, Ljubica Pavlović ${ }^{2}$ Jovica Stojanović ${ }^{2}$, Zagorka Radojević ${ }^{1}$ \\ ${ }^{1}$ Institute for Materials Testing - IMS, Belgrade, Serbia \\ ${ }^{2}$ Institute ITNMS, Belgrade, Serbia \\ \#anja.terzic@institutims.rs
}

\begin{abstract}
Building composites - thermo-insulating and/or high-temperature resistant bonding agents in which fly ash, as potentially environmentally harmful waste material, is combined with ordinary and refractory cement is new option for reapplication of this waste material. In this study, investigated bonding agents were based on two types of fly ashes from coal combustion process and cements - ordinary Portland cement and highaluminate cement. Change of mineral phase composition of the composites with increasing temperature was analyzed by means of XRD method. Microstructural changes within investigated composites were investigated by means of scanning electron microscopy (SEM). Macro-performance - mechanical properties of the investigated bonding agents was finally correlated with its microstructure. The investigated bonding agents showed excellent compressive strength, while SEM and XRD analysis indicated its valuable refractory and thermo-insulation properties.
\end{abstract}

Key words: Portland cement, high-aluminate cement, fly ash, XRD, microstructure, mechanical behavior.

\section{INTRODUCTION}

Ash produced during coal combustion in power-plants is considered as one of the most hazardous environmental polluters. According to estimation, the annual global fly ash production was more than 600 million tons in past 10 years [1]. In the European Union the total production of fly ash is estimated to be about 95 million tons [2]. Fly ash represents about $80 \%$ of coal-ash produced by thermal power plants, while bottom ash

Received October 10, 2012

* Acknowledgement. This investigation was supported by Serbian Ministry of Science and Education and it was conducted under following projects: 172057 and 45008. 
accounts for $10-15 \%$ [3]. The fly ash generation is a global problem with severe implications for the environment: elements may leak through the soil to the groundwater; ash might cause air pollution if left on open landfills, etc. For industry, high costs of storage, transport and disposal must be faced by plant operators and waste management companies. EU regulations are focused on the recycling of the coal combustion fly ash and reusing it as a component of building materials, namely 21 million tons of fly ash is being reapplied annually in the construction industry [4]: as concrete/mortar addition - bonding agent or aggregate [5-8], in road construction [9], in cement clinker production [10, 11], for bricks and tiles [12,13], for infill of voids and as geopolymers [14-16]. The high recycling rates the fly ash achieved are mainly due to its pozzolanic behavior [17].

However, since there is a perpetual request for new applications of fly ash, one of suggested ways of using this waste material is in thermo-insulators and high-temperature building composites. As such, fly ash has to adequately meet mechanical and thermal stability criteria. Substantial amount of studies related with fly ash performances in cementitious materials promotes its consistency and long-term strength enhancement [18-23]. The improved performances are related with the more spherical shape and smooth texture of fly ash compared to cement particles. Cement particles gain rough and angular shape as the result of clinker grinding. Spherical and smooth fly ash particles help the mixture interparticle friction reducing. Fly ash acts as superplasticizing admixture helping the "packing" of composite structure. Superplasicizing ability leads to reduction of water content needed for optimal mixture consistency and, thus, increasing of mechanical strength.

Another important property of such materials is its behavior at elevated temperatures: thermo-insulation properties, fire resistance and finally possible refractoriness. The use of fly ash additions in building composites can affect the material behavior when subjected to elevated temperature [24]. Materials that retain a large quantity of water are more desirable for fire protection and thermal exposure. Namely, when these materials are exposed to a thermal source, part of the water evaporates and is transported from the exposed surface to the interior of the material where the water cools and condenses again. Afterwards, a liquid film forms which is displaced towards the unexposed side. Some commercial products, used as thermal insulation or passive fire protection in buildings and industrial installations, have a chemical composition and properties similar to fly ash mixtures [25-29].

In the present study, fly ash-cement based composites were subjected to several thermal, mechanical and microstructural analyses in order to investigate behavior under elevated temperature, the mechanical properties and the environmental impact.

\section{EXPERIMENTAL PROGRAM}

\subsection{Materials applied in the investigation: fly ash and cement}

The fly ash used in the investigation originates from the filter systems of two coalfired power plants in Serbia. Two representative types of fly ash chosen for the investigation are labeled as FA1 and FA2. The fly ash was collected directly from the filter system of the power plant. Afterwards the fly ash was transported to a special closed silo for storing. A sample of $500 \mathrm{~kg}$ of each fly ash was randomly taken from the silo and re-sampled by the quarter method. Thus, $50 \mathrm{~kg}$ samples were obtained. The samples were pre- 
served in hermetically sealed boxes until further analyses. Grain size distribution of the fly ash is given in Fig. 1.

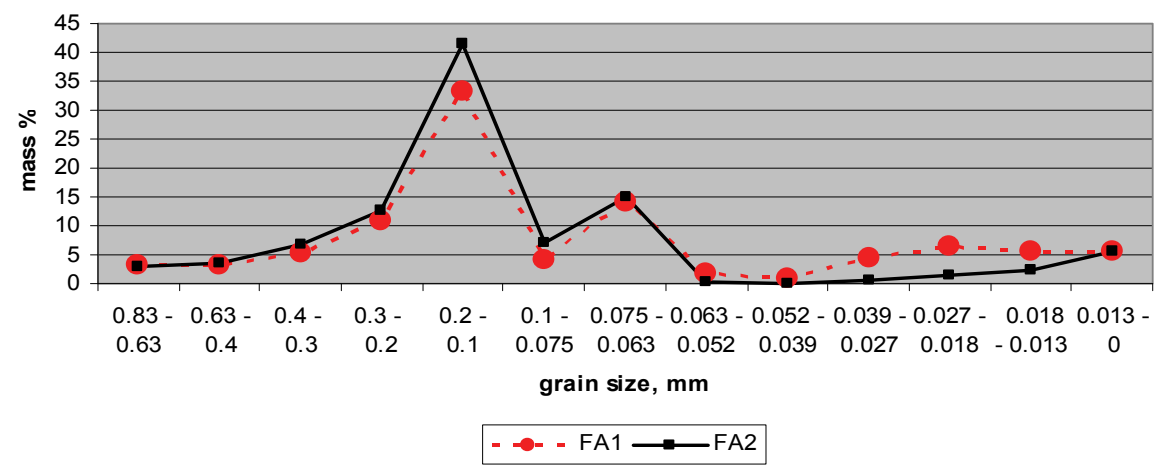

Fig. 1. Distribution of fly ash grain fractions given in percentage of total mass

Two types of cement were used in the investigation: standard Portland cement (PC 42.5R Lafarge) and high-aluminate/calcium-aluminate cement (HAC Secar 70/71, Lafarge). $88.29 \%$ particles of $\mathrm{HAC}$ and $97.48 \%$ particles of PC were in range $-0.63+0.00 \mathrm{~mm}$. Chemical composition of HAC, PC, FA1 and FA2 is given in Tab.1

Table 1. Chemical analysis of fly ash and cement.

\begin{tabular}{crrrr}
\hline Oxides, wt.\% & FA1 & FA2 & PC & HAC \\
\hline $\mathrm{SiO}_{2}$ & 53.45 & 53.32 & 19.28 & 0.11 \\
$\mathrm{Al}_{2} \mathrm{O}_{3}$ & 21.28 & 19.08 & 6.39 & 70.85 \\
$\mathrm{Fe}_{2} \mathrm{O}_{3}$ & 7.11 & 6.98 & 2.93 & 0.05 \\
$\mathrm{TiO}_{2}$ & 0.56 & 0.57 & $<0.1$ & 0.01 \\
$\mathrm{CaO}$ & 7.61 & 9.71 & 59.57 & 27.73 \\
$\mathrm{MgO}$ & 2.74 & 3.3 & 1.56 & 0.07 \\
$\mathrm{P}_{2} \mathrm{O}_{5}$ & 0.03 & 0.02 & - & - \\
$\mathrm{SO}_{3}$ & 0.78 & 1.29 & - & - \\
$\mathrm{Na}_{2} \mathrm{O}$ & 0.44 & 0.5 & 0.02 & 0.28 \\
$\mathrm{~K}_{2} \mathrm{O}$ & 1.21 & 1.16 & 0.03 & 0.04 \\
$\mathrm{MnO}_{\mathrm{CO}}$ & 0.03 & 0.03 & - & - \\
$\mathrm{CO}_{2}$ & 0.25 & 0.11 & - & - \\
\hline
\end{tabular}

\subsection{Preparation and curing of the composites}

Cement - fly ash based composites/bonding agents were prepared for further analyses. The composites contained $30 \%$ of fly ash and $70 \%$ of cement. The composites were labeled as: BA1 $(\mathrm{PC}+\mathrm{FA} 1), \mathrm{BA} 2(\mathrm{HAC}+\mathrm{FA} 1), \mathrm{BA} 3(\mathrm{PC}+\mathrm{FA} 2)$ and $\mathrm{BA} 4(\mathrm{HAC}+$ FA2). Analysis was conducted in accordance with standards for cement quality: HAC SRPS EN 14647:2008/AC:2008 (analogue to EN 14647:2005/AC:2006 and CEN/TC 51) and PC -SRPS EN 197-1:2010 (analogue to EN 197-1:2000/A3:2007 and CEN/TC 51). Composites were mixed for 8 minutes in laboratory RILEM-cem mixer and, afterwards, shaped in $2 \mathrm{~cm}$ cubic moulds. After 7 days of curing in a climate chamber at $20^{\circ} \mathrm{C}$ and 
humidity $60 \%$, the samples were demoulded and stored for another 21 days under the same conditions as in the climate chamber. Chemical analysis of the composites is given in Table 2.

Table 2. Chemical analysis of the bonding agents.

\begin{tabular}{ccccc}
\hline Oxides, wt. $\%$ & $\mathrm{BA} 1$ & $\mathrm{BA} 2$ & $\mathrm{BA} 3$ & $\mathrm{BA} 4$ \\
\hline $\mathrm{SiO}_{2}$ & 31.0 & 17.50 & 29.63 & 16.08 \\
$\mathrm{Al}_{2} \mathrm{O}_{3}$ & 10.22 & 54.59 & 10.95 & 55.30 \\
$\mathrm{Fe}_{2} \mathrm{O}_{3}$ & 4.27 & 2.08 & 4.10 & 1.91 \\
$\mathrm{TiO}_{2}$ & 0.17 & 0.16 & 0.17 & 0.16 \\
$\mathrm{CaO}$ & 44.64 & 23.23 & 44.31 & 22.93 \\
$\mathrm{MgO}$ & 2.0 & 0.79 & 2.13 & 0.92 \\
$\mathrm{P}_{2} \mathrm{O}_{5}$ & 0.02 & - & 0.06 & \\
$\mathrm{SO}_{3}$ & 2.15 & 0.32 & 2.00 & 0.17 \\
$\mathrm{Na}_{2} \mathrm{O}$ & 0.36 & 0.35 & 0.36 & 0.35 \\
$\mathrm{~K}_{2} \mathrm{O}$ & 0.76 & 0.345 & 0.75 & 0.345 \\
$\mathrm{MnO}_{3}$ & 0.1 & - & 0.08 & - \\
$\mathrm{CO}_{2}$ & 0.03 & - & 0.02 & - \\
$\mathrm{LOI}$ & 3.62 & 1.45 & 3.89 & 1.74 \\
\hline
\end{tabular}

\subsection{Applied methods of investigation}

$\mathrm{X}$-ray fluorescence (XRF) technique was used to conduct chemical analysis of the fly ash, cements and composites. Analysis was performed by means of XRF spectrophotometer ED 2000 - Oxford. The international reference material obtained from the $\mathrm{Na}$ tional Institute of Standards \& Technology, USA, was applied in verification of the accuracy of results of the analysis. The loss of ignition (LOI) of fly ash was determined by the weight difference between room temperature and $1000{ }^{\circ} \mathrm{C}$. The maximum temperature was held constantly for 4 hours.

Fraction content of the fly ash samples was analyzed by means of cyclo-sizer diffraction particle size analysis (Cyclo-sizer Warman International LTD, Australia). Grain size distribution of the mechano-activated fly ash is given in Fig. 1

The mechanical compressive strength (MCS) of composite samples was tested using a conventional laboratory hydraulic pressure device. Samples were tested on MCS at ambient temperature. Afterwards, the samples were fired in an electric furnace at following temperatures: 900, 1100 and 1300. The thermal treatment interval used was 2 hours at each temperature. Heating rate was $150^{\circ} \mathrm{C} / \mathrm{h}$. After firing sample were tested on MCS.

Milled, homogenized and dried (for $6 \mathrm{~h}$ at $105^{\circ} \mathrm{C}$ ) composite samples were analyzed by means of X-ray powder diffraction (XRD). The XRD patterns were obtained on a Philips $P W-1710$ automated diffractometer using a Cu tube operated at $40 \mathrm{kV}$ and $30 \mathrm{~mA}$. The instrument was equipped with a diffracted beam curved graphite monochromator and a Xe-filled proportional counter. The diffraction data were collected in the $2 \theta$ Bragg angle range from 5 to $70^{\circ}$, counting for $1 \mathrm{~s} \mathrm{(qualitative} \mathrm{identification)} \mathrm{at} \mathrm{every} 0.02^{\circ}$ step. The divergence and receiving slits were fixed 1 and 0.1 , respectively. All the XRD measurements were performed at room temperature in a stationary sample holder.

The microstructure of the fly ash samples and composites was characterized by scanning electron microscopy method (SEM) using a JEOL JSM-6390 Lv microscope. Com- 
posite samples were crushed, and parts of original samples were used in SEM investigation. The samples were covered with gold powder for better reflection to be obtained and measurements performed.

\section{RESULTS OF THE EXPERIMENTS AND DISCUSSION}

From the chemical composition analysis of the composites presented in Tab. 2., it can be seen composites consist mainly of silica, alumina, calcium and iron oxides. Due to the chemical composition of applied cement, composites BA1 and BA3 have increased $\mathrm{CaO}$ content (approximately $44 \%$ ) in comparison with $\mathrm{BA} 2$ and $\mathrm{BA} 4$ whose $\mathrm{CaO}$ content is app. $23 \% . \mathrm{Al}_{2} \mathrm{O}_{3}$ content in $\mathrm{HAC}$ based composites is app. $55 \%$. Application of fly ash increased $\mathrm{SiO}_{2}$ content in the composites in comparison with starting composition of applied cements. $\mathrm{SiO}_{2}$ content in fly ashes was higher than $50 \%$, while content of $\mathrm{Al}_{2} \mathrm{O}_{3}$ approximately was about $20 \%$. Therefore investigated fly ashes can be classified as alumino-silicate ashes, which is the category of ashes attributed with excellent pozzolanic behavior which is of huge importance when fly ash is applied as partial substitution of cement in bonding agent composite.

XRD diffractograms of investigated cements as result of the mineralogical analysis are given in Figure 2. and 3.

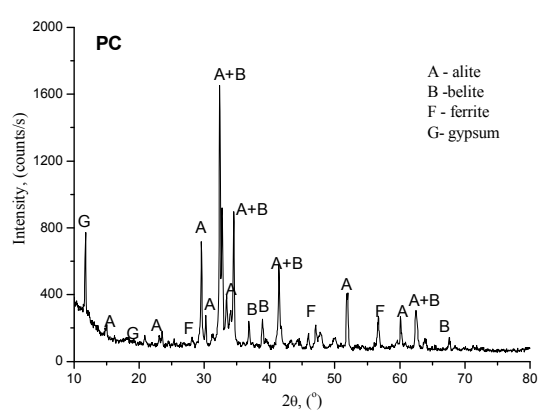

Fig. 2. XRD diffractograms of $P C$

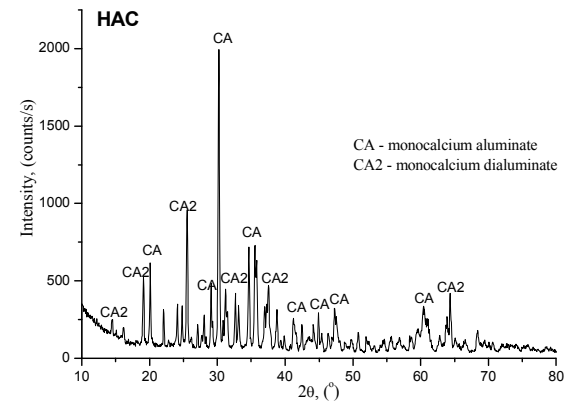

Fig. 3. XRD diffractograms of HAC

Phase compositions of PC and HAC are different due to the differences in the cement manufacturing procedure. Identified crystalline major phases present in the Portland cement sample were: alite - tricalcium silicate: $\left(\mathrm{Ca}_{3} \mathrm{SiO}_{5}, 3 \mathrm{CaO} \cdot \mathrm{SiO}_{2}, \mathrm{C}_{3} \mathrm{~S}\right)$, belite - dicalcium silicate $\left(\mathrm{Ca}_{2} \mathrm{SiO}_{4}, 2 \mathrm{CaO} \cdot \mathrm{SiO}_{2}, \mathrm{C}_{2} \mathrm{~S}\right)$, ferrite - calcium aluminoferrite/brown-millerite $\left(\mathrm{Ca}_{2}(\mathrm{Al}, \mathrm{Fe})_{2} \mathrm{O}_{5}\right)$ and gypsum $-\left(\mathrm{Ca}_{2} \mathrm{SiO}_{4}\left(\mathrm{H}_{2} \mathrm{O}\right)_{2}\right)$. The main defined peaks on diffractograms relate to alite and belite (Fig.2). In case of HAC cement the main defined peaks correspond to monocalcium aluminate $\mathrm{CaO} \cdot \mathrm{Al}_{2} \mathrm{O}_{3}(\mathrm{CA})$ and monocalcium dialuminate $\mathrm{CaO} \cdot 2 \mathrm{Al}_{2} \mathrm{O}_{3}$ (CA2) which were only two crystalline phases found in the sample (Fig. 3).

XRD diffractograms of investigated fly ashes are given in Figures 4. and 5. 


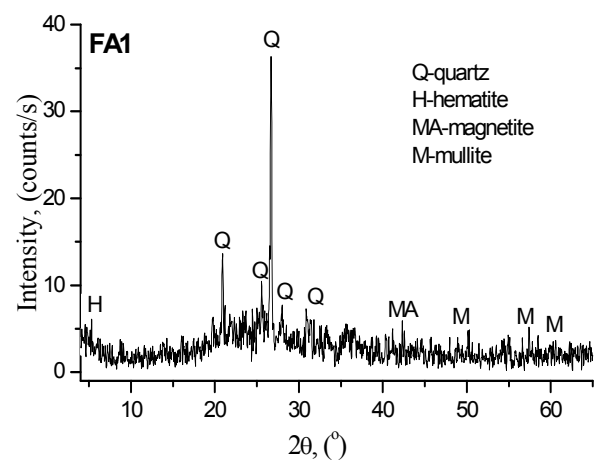

Fig. 4. XRD diffractograms of FA1

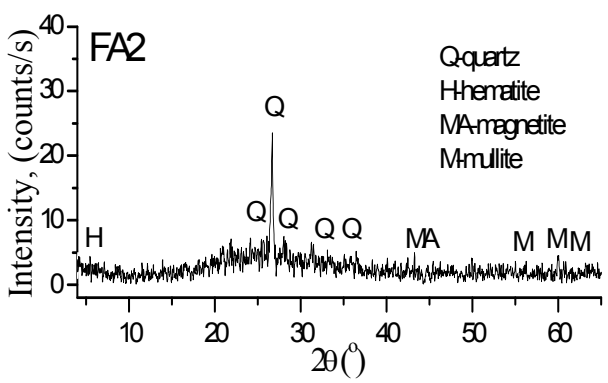

Fig. 5. XRD diffractograms of FA2

Very few differences in phase compositions of investigated fly ashes were noted. Identified crystalline major phases present in both samples were aluminosilicate glass, quartz and mullite. The main defined peaks on diffractograms relate to quartz. High amount of amorphous matter was present within all investigated fly ash samples. The background hump between 10 and $40^{\circ}$ in the X-ray spectrum provided additional evidence of the presence of an amorphous phase. Magnetite, hematite, fluorite and anhydrite were noted in relatively negligible amounts. The small differences observed in the mineralogical composition might be attributed to the heterogeneity of the fly ash composition, i.e. coal used or combustion process applied. Sample FA2 showed lower level of crystallinity and, thus, high amount of amorphous material and low quartz and mullite content. At the other hand, the sample FA1 has the more defined quartz peak on diffractogram, i.e. the higher level of crystallinity.

Mineral phase changes induced by increasing temperature within investigated bonding agent composites were followed by means of XRD (Figures 5.-8.)

Phase composition of the analyzed sample BA1 at $20{ }^{\circ} \mathrm{C}$ is as follows (Fig 5.): alite, belite/larnite, tricalcium aluminate, quartz, portlandite $\left(\mathrm{Ca}(\mathrm{OH})_{2}\right)$. Crystallinity degree of all present phases is very poor. Phase composition at $900{ }^{\circ} \mathrm{C}$ is slightly changed: alite, 
belite/larnite, $\mathrm{Ca}_{2} \mathrm{Al}_{2} \mathrm{SiO}_{7}$ (gehlenite) and $\mathrm{SiO}_{2}$ (quartz). There is no present portlandite. Phase composition of the sample characterizes beginning of crystallization of gehlenite. Crystallinity degree is slightly higher in comparison to the previous sample mostly because of gehlenite. At $1100{ }^{\circ} \mathrm{C}$ gehlenite and $\mathrm{Ca}_{3} \mathrm{Si}_{2} \mathrm{O}_{7}$ were found. Besides these crystal phases there is also a small possibility of existence of low amounts of quartz. Gehlenite is more much abundant than rankinite. Crystallinity degree is notably higher in comparison to the previous two samples. At $1300{ }^{\circ} \mathrm{C}$ phase composition and crystallinity degree is the same as previous sample.
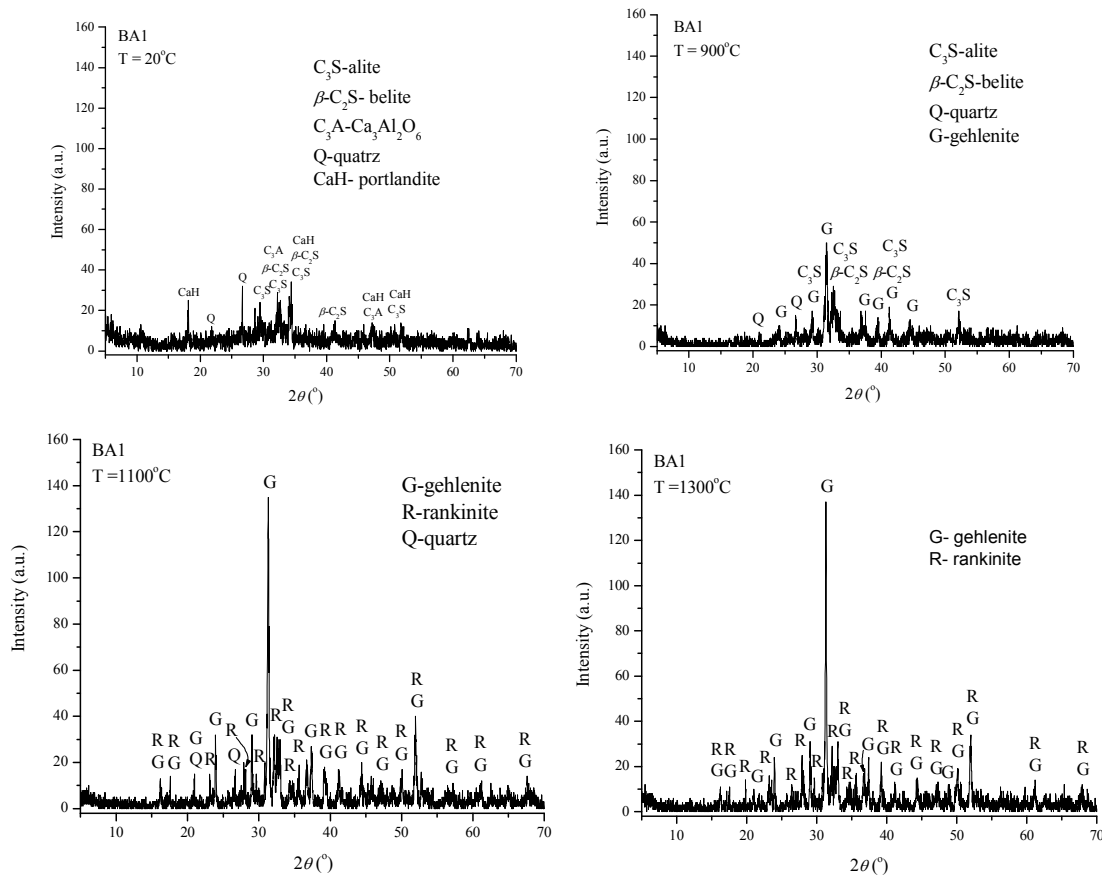

Fig. 5. Mineral phase changes induced by increasing temperature: XRD diffractograms of BA1.

Phase composition of the BA2 (at $\mathrm{T}=20{ }^{\circ} \mathrm{C}$ ) is (Fig. 6): alite, belite, tricalcium aluminate, quartz, portlandite. Crystallinity degree of all present phases is very poor. BA2 at $\mathrm{T}=900{ }^{\circ} \mathrm{C}$ shows following phase composition: alite, belite/larnite, gehlenite, quartz. Phase composition of the sample characterizes beginning of crystallization of gehlenite. Crystallinity degree is slightly higher in comparison to the previous sample mostly because of gehlenite. At $\mathrm{T}=1100{ }^{\circ} \mathrm{C}$ following phase composition was detected: gehlenite, rankinite. Besides these crystal phases there is also a small possibility of existence of low amounts of alite and belite. Crystallinity degree is notably higher in comparison to the previous two samples. At $\mathrm{T}=1300{ }^{\circ} \mathrm{C}$ phase composition and crystallinity degree is the same as previous sample: gehlenite and rankinite.

Differences between phase compositions and phase temperature changes for samples BA1 and BA2 are insignificant, which leads to conclusion that despite different origin of fly ashes applied the composite samples will not have significantly different properties. 

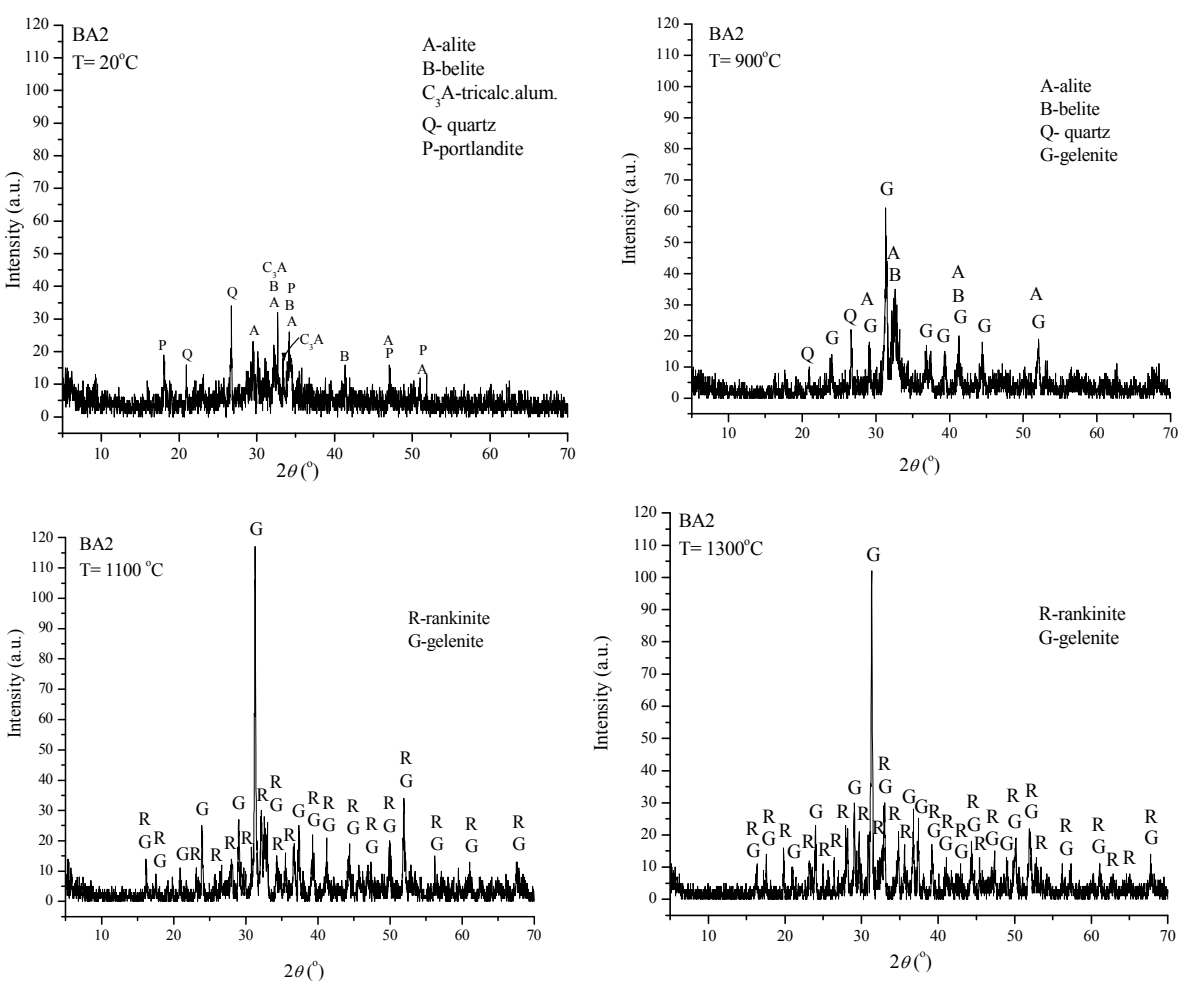

Fig. 6. Mineral phase changes induced by increasing temperature: XRD diffractograms of BA2.

Phase composition of the BA3 sample at $20^{\circ} \mathrm{C}$ (Fig. 7) is as follows: $\mathrm{CaAl}_{2} \mathrm{O}_{4}, \mathrm{CaAl}_{4} \mathrm{O}_{7}$, $\mathrm{CaAl}_{2} \mathrm{O}_{4} \cdot 10 \mathrm{H}_{2} \mathrm{O}$, quartz, and amorphous matter. The most abundant phase is $\mathrm{CaAl}_{2} \mathrm{O}_{4}$, $\mathrm{CaAl}_{4} \mathrm{O}_{7}$ is less abundant, $\mathrm{CaAl}_{2} \mathrm{O}_{4} \cdot 10 \mathrm{H}_{2} \mathrm{O}$ and quartz are present in the smallest amounts in the sample. Crystallinity degree of all present phases is very low. Phase composition analyzed at temperature $900{ }^{\circ} \mathrm{C}$ is as: $\mathrm{CaAl}_{2} \mathrm{O}_{4}, \mathrm{CaAl}_{4} \mathrm{O}_{7}$, gehlenite, $\mathrm{Ca}_{2} \mathrm{Al}_{2} \mathrm{Si}_{2} \mathrm{O}_{8}$ (anorthite), quartz, and amorphous matter. Phase composition of the sample characterizes beginning of crystallization of gehlenite and anorthite. Moreover, $\mathrm{CaAl}_{2} \mathrm{O}_{4}$ and $\mathrm{CaAl}_{4} \mathrm{O}_{7}$ are present in nearly equal amounts, while gehlenite and anorthite are lesser abundant. Quartz is present in the smallest amounts in the sample. Crystallinity degree of all present phases is even lower in comparison to the previous sample. At $1100{ }^{\circ} \mathrm{C}$ recorded phases are same as at previous temperature: $\mathrm{CaAl}_{2} \mathrm{O}_{4}, \mathrm{CaAl}_{4} \mathrm{O}_{7}$, gehlenite, anorthite, quartz and amorphous matter. However, in this sample $\mathrm{CaAl}_{4} \mathrm{O}_{7}$ is the most abundant, while presence of $\mathrm{CaAl}_{2} \mathrm{O}_{4}$ along with gehlenite, anorthite and quartz are much lesser. Crystallinity degree is slightly higher in comparison to the previous sample and amorphous matter is less present. At highest temperature $\left(1300^{\circ} \mathrm{C}\right)$ phase composition of the analyzed sample is as follows: gehlenite, $\mathrm{Al}_{2} \mathrm{O}_{3}$ (corundum), $\mathrm{CaAl}_{4} \mathrm{O}_{7}$, anorthite, $\mathrm{SiO}_{2}$ (cristobalite). The most abundant phase is gehlenite, while less present phases are anorthite, corundum and $\mathrm{CaAl}_{4} \mathrm{O}_{7}$. There is also possibility of presence of cristobalite but in very small amounts. Crystallinity degree is the highest in comparison to the all previous samples. 

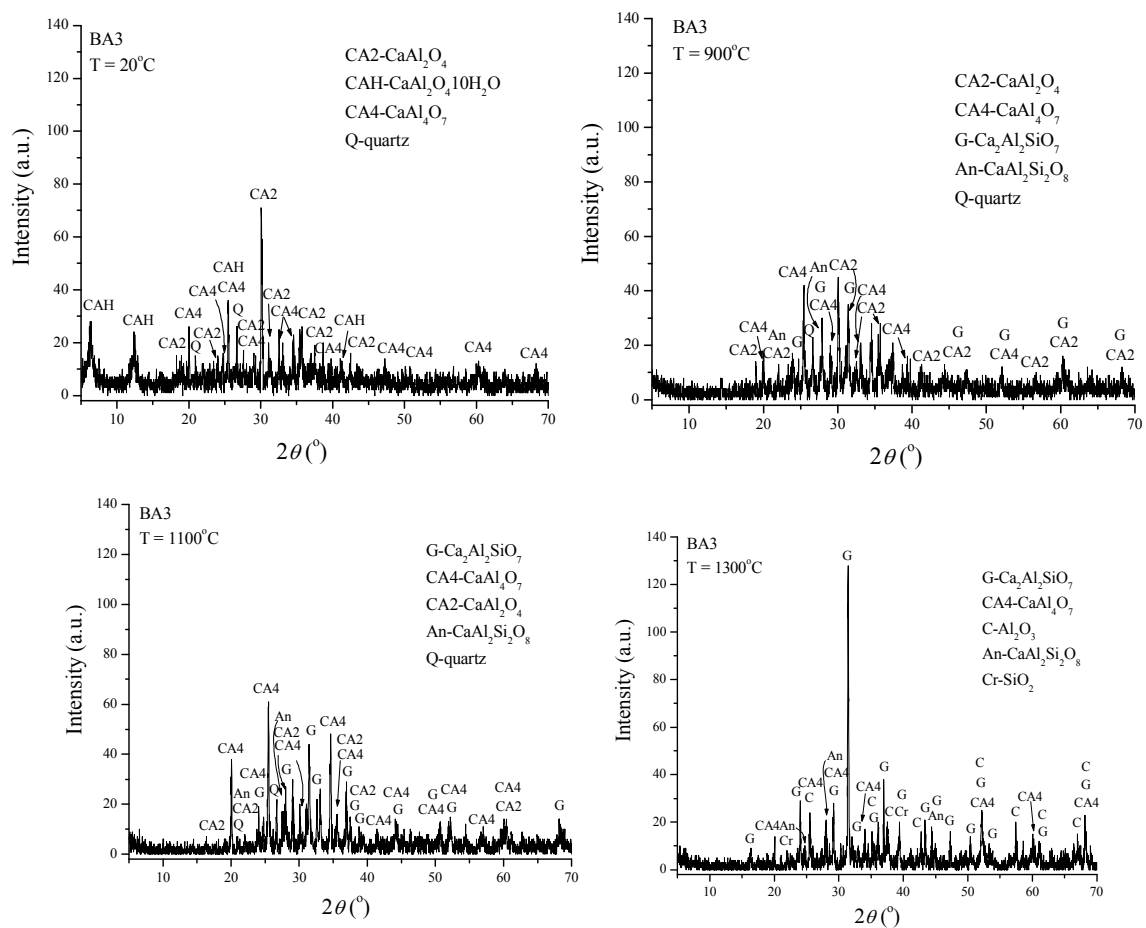

Fig. 7. Mineral phase changes induced by increasing temperature: XRD diffractograms of BA3.

Phase composition of the BA4 (at $\mathrm{T}=20{ }^{\circ} \mathrm{C}$ ) is as follows (Fig.8.): monocalcium aluminate, grossite $\left(\mathrm{CaAl}_{4} \mathrm{O}_{7}\right)$, calcium aluminium decahydrate $\left(\mathrm{CaAl}_{2} \mathrm{O}_{4} \cdot 10 \mathrm{H}_{2} \mathrm{O}\right)$, quartz and amorphous matter. The most abundant phase is $\mathrm{CaAl}_{2} \mathrm{O}_{4}, \mathrm{CaAl}_{4} \mathrm{O}_{7}$ is less abundant, $\mathrm{CaAl}_{2} \mathrm{O}_{4} \cdot 10 \mathrm{H}_{2} \mathrm{O}$ and quartz are present in the smallest amounts in the sample. Crystallinity degree of all present phases is very low. Same sample at $\mathrm{T}=900{ }^{\circ} \mathrm{C}$ shows following phase composition: $\mathrm{CaAl}_{2} \mathrm{O}_{4}, \mathrm{CaAl}_{4} \mathrm{O}_{7}$, gehlenite, anorthite, quartz, and amorphous matter. Phase composition of the sample characterizes beginning of crystallization of gehlenite and anorthite. Moreover, $\mathrm{CaAl}_{2} \mathrm{O}_{4}$ and $\mathrm{CaAl}_{4} \mathrm{O}_{7}$ are present in nearly equal amounts, while gehlenite is lesser abundant. Crystallinity degree of all present phases is even lower in comparison to the previous sample. At $\mathrm{T}=1100{ }^{\circ} \mathrm{C}$ following phase composition was detected: $\mathrm{CaAl}_{2} \mathrm{O}_{4}, \mathrm{CaAl}_{4} \mathrm{O}_{7}$, gehlenite, anorthite, quartz, and amorphous matter. However, in this sample $\mathrm{CaAl}_{4} \mathrm{O}_{7}$ and gehlenite are most abundant, while presence of $\mathrm{CaAl}_{2} \mathrm{O}_{4}$ is much lesser. Crystallinity degree is notably higher in comparison to the previous two samples and amorphous matter is less present. At $\mathrm{T}=1300{ }^{\circ} \mathrm{C}$ phase composition is: gehlenite, corundum, $\mathrm{CaAl}_{4} \mathrm{O}_{7}$, anorthite, cristobalite. The most abundant phase is gehlenite, while less present phases are $\mathrm{CaAl}_{4} \mathrm{O}_{7}$, corundum and anorthite. There is also possibility of presence of cristobalite but in very small amounts. Crystallinity degree is the highest in comparison to the all previous samples.

Same as in case of PC based composites, phase compositions of BA3 and BA4 have very few differences. However crystallinity of BA4 is significantly higher. 

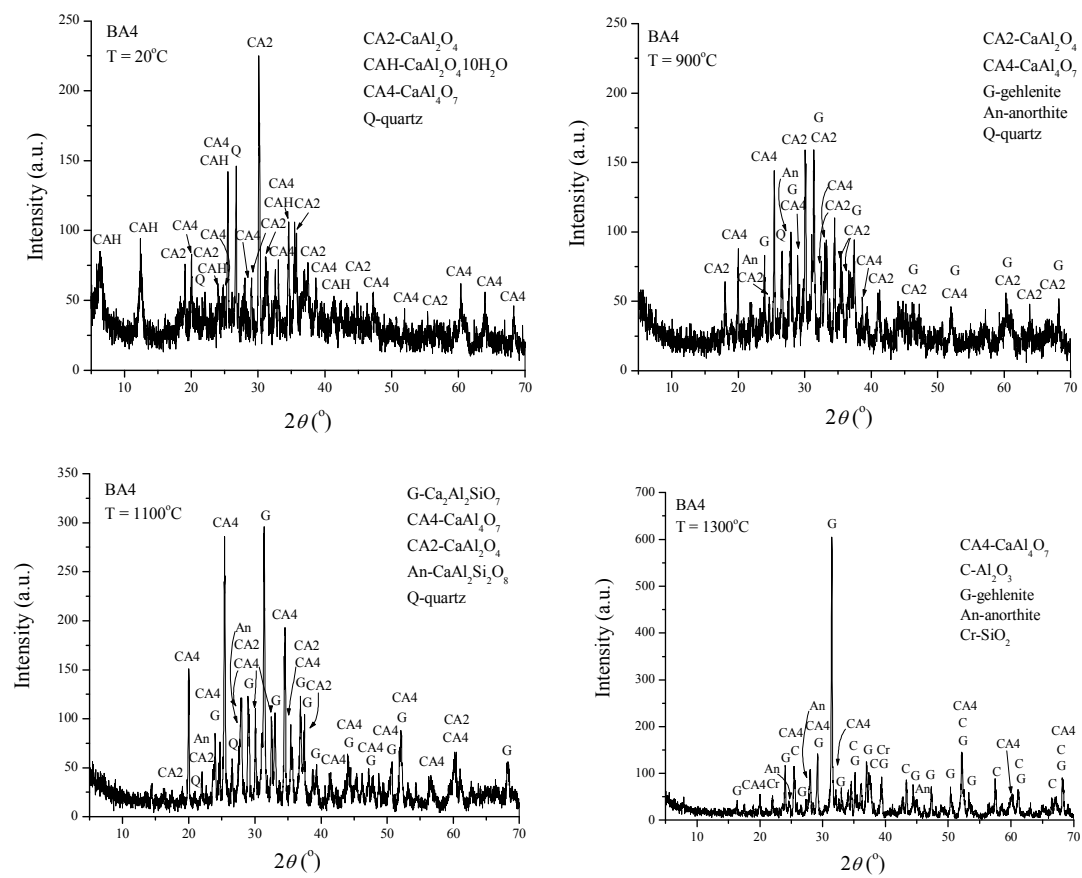

Fig. 8. Mineral phase changes induced by increasing temperature: XRD diffractograms of BA4.

The bonding agents BA1-4 XRD analysis highlighted certain thermally induced phase changes taking place. The XRD spectra in all cases were very complex and the XRD patterns revealed that with an increase of temperature, more complex aluminosilicates were formed, especially in HAC based composites (BA3 and BA4). In case of BA1 and BA2, the number of the minerals was reduced with increasing temperature. It is possible that simple minerals were gradually incorporated into the complex aluminosilicates during thermal treatment of the samples. The fly ash normally contains significant amount of siliceous glass together with the crystalline phases - quartz, hematite and mullite. Thermal treatment reduced the amount of glassy phase and quartz, and promoted formation of anorthite, mullite, hematite and cristobalite. However, the diffraction peaks of these compounds in composite samples were broad or poorly developed or overlapping with other peaks. The formation of rankinite, gehlenite, anorthite and cristobalite in the composites is important because they are thermally stable (i. e. have high melting point) and therefore they contribute to the thermal stability of the composites.

The thermally induced change of compressive strength, as representative property of a bonding-agent performance, is given in Figure 9. Investigated composites were exposed to high temperatures $\left(900,1100\right.$ and $\left.1300{ }^{\circ} \mathrm{C}\right)$ during 2 hours. Obtained values of compressive strengths for all composite types are high, reaching over $100 \mathrm{MPa}$ for BA3 and BA4 composites and near $100 \mathrm{MPa}$ for BA1 and BA2 composites. Surely, such values should be reduced by dimensional factor; i.e. smaller-sized samples give higher strength 
values. However, it should be highlighted that increasing temperature, after expected initial decrement of compressive strength, induced porosity reduction which, along other changes (like previously explained phase changes and initiation of sintering process) resulted in increasing of compressive strength.

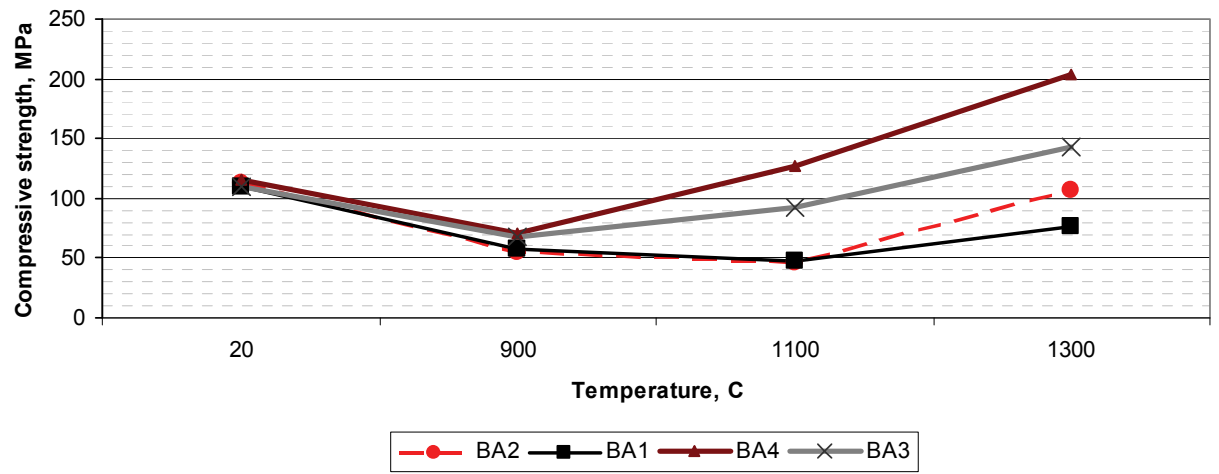

Fig. 9. The change of compressive strength of the composites during exposure to high temperature

Figure 10. shows detail of BA1 sample $\left(T=20^{\circ} \mathrm{C}\right)$ recorded by means of SEM at 1000x magnification. Fly ash grains of different sizes can be seen incorporated in cement matrix. Fly ash grains are spherical while cement grains are irregularly shaped. Spherical fly ash grains helped better "packing" of the microstructure and thus promoted strength increasing. Also, it can be seen that fly ash grains are highly porous, usually containing smaller sized spheres within huge hollow particles.

The SEM microphotographs of composites BA2 and BA4 recorded after samples firing at $1300{ }^{\circ} \mathrm{C}$ at $800 \mathrm{x}$ magnification, are given in Figs. 11. and 12, respectively. Porosity of BA4 sample is lower, i.e. pores are less notable than in case of BA2 sample which explains its higher compressive strength. The bond between fly ash and cement particles seems to be quite strong which indicates that these two materials are thermally compatible.

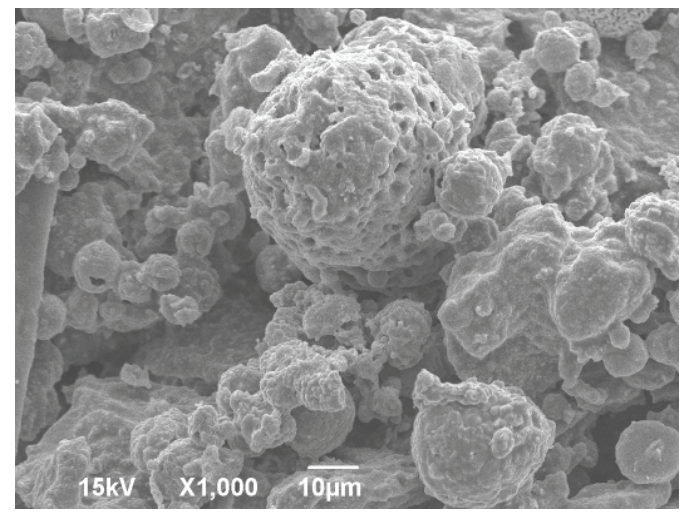

Fig. 10. The SEM microphotograph of BA1 


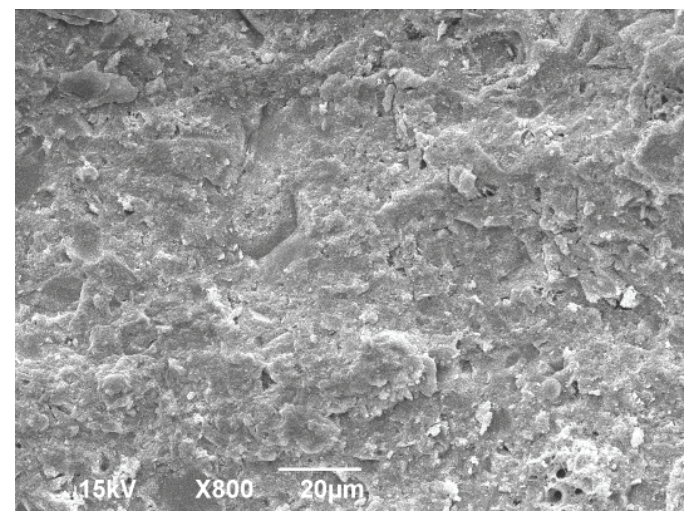

Fig. 11. The SEM microphotographs of $\mathrm{BA} 2$ at $\mathrm{T}=1300^{\circ} \mathrm{C}$.

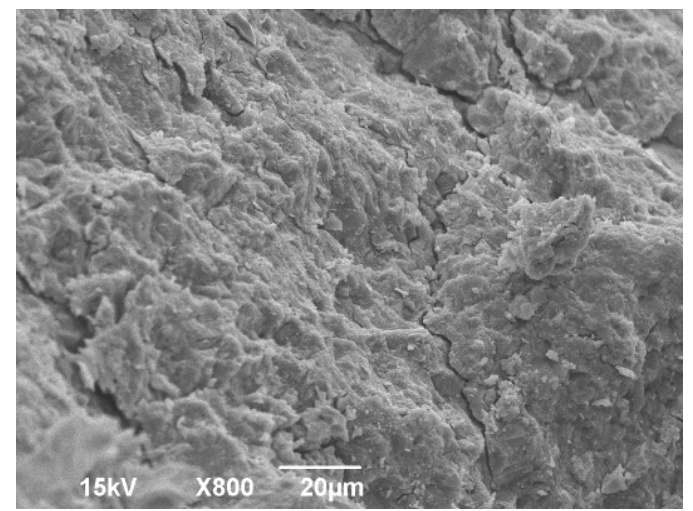

Fig. 12. The SEM microphotograph of $\mathrm{BA} 4$ at $\mathrm{T}=1300{ }^{\circ} \mathrm{C}$

\section{CONCLUSION}

The investigated composites based on cement and fly ash, as reapplied waste material, seem to be a promising thermal-insulation and high temperature resistant material which can be used as bonding agent. Such bonding agent can be applied in concrete or mortar mixtures and used for structural elements that are exposed to high temperatures. The investigation highlighted following: fly ash, as recycled raw material, showed satisfactory behavior at elevated temperatures and, thusly it has positive thermal insulation and temperature behavior; The spherically shaped fly ash grains have characteristic of superplasicizing additive and by such they promoted strength enhancement to a certain level and, thus improved performances of investigated composites by minimizing microstructural incompatibility. Fly ash being applied as super plasticizer fills voids irregular cement particles leave behind and decrease level of porosity; Melting of the composites is not recorded at the temperature $1300{ }^{\circ} \mathrm{C}$ which attributes to good refractory characteristics of investigated composites; XRD showed that crystallinity of the composites improved with increasing temperature. The formation of rankinite, gehlenite, anorthite and cristobalite in 
the composites is important because they are thermally stable and therefore they contribute to the thermal stability of the composites.

\section{REFERENCES}

1. Thakur R.N., Ghosh S., Effect of mix composition on compressive strength and microstructure of fly ash based geopolymer composites, Journal of Engineering and Applied Sciences 4 (2009) 65-70

2. Feuerborn H., Coal ash utilisation over the world and in Europe, Workshop on Environmental and Health Aspects of Coal Ash Utilization (2005) Tel-Aviv, Israel

3. Wang S., Baxter L., Fonseca F., Biomass fly ash in concrete: SEM, EDX and ESEM analysis, Fuel 87 (2008) 372-379.

4. Medina A., Gamero P., Querol X., Moreno N., De León B., Almanza M., Vargas G., Izquierdo M., Font O., Fly ash from a Mexican mineral coal I: Mineralogical and chemical Characterization, J. Hazard. Mater. 181 (2010) 82-90.

5. Lee H.K., Kim H.K., Hwang E.A., Utilization of power plant bottom ash as aggregates in fiberreinforced cellular concrete. Waste Management 30 (2010) 274-284.

6. Li G., A new way to increase the long-term bond strength of new-to-old concrete by the use of fly ash, Cement and Concrete Research 33 (2003) 799-806

7. Kockal N.U., Ozturan T., Effects of lightweight fly ash aggregate properties on the behavior of lightweight concretes, J. Hazard. Mater. 179 (2010) 954-965.

8. Cinquepalmi M., Mangialardi T., Panei L., Evangelista Paolini A., Piga L., Reuse of cement-solidified municipal incinerator fly ash in cement mortars: Physico-mechanical and leaching characteristics, Journal of Hazardous Materials 151 (2008) 585-593.

9. Mulder E., A Mixture of Fly Ash as Road Base Construction Material, Waste Managment 16 1-3 (1996) 15-20.

10. Guerrero A., Goni S., Allegro V.R., Durability of class C fly ash belite cement in simulated sodium chloride radioactive liquid waste: Influence of temperature, J. Hazard. Mater. 162 (2009) 1099-1102.

11. Lilkov V., Petrov O., Tzvetanova Y., Savov P., Mössbauer, DTA and XRD study of Portland cement blended with fly ash and silica fume Construction and Building Materials 29 (2012) 33-41.

12. Erol M., Kucukbayrak S., Ersoy-Mericboyu A., Comparison of the properties of glass, glass-ceramic and ceramic materials produced from coal fly ash, J. Hazard. Mater. 153 (2008) 418-425.

13. Haiying Z., Youcai Z., Jingyu Q., Study on use of MSWI fly ash in ceramic tile, Journal of Hazardous Materials 141 (2007) 106-114.

14. Davidovits J., Geopolymers: inorganic polymeric new materials, J. Therm. Anal. 37 (1991) 1633-1656.

15. Izquierdo M., Querol X., Phillipart C., Antenuc D., Towler M., The role of open and closed curing conditions on the leaching properties of fly ash-slag-based geopolymers, Jour. Hazard. Mater. 176 (2010) 623-628

16. Williams R., van Riessen A., Determination of the reactive component of fly ashes for geopolymer production using XRF and XRD, Fuel 89 (2010) 3683-3692

17. Malhotra VM, Mehta PK. High-performance, high-volume fly ash concrete,supplementary cementing materials for sustainable development. Otawa:Marquardt Printing; 2002.

18. Felekoglu B. Utilisation of Turkish fly ashes in cost effective HVFA concrete production. Fuel 85 (2006)1944-9.

19. Bouzoubaa N, Zhang MH, Malhotra VM. Mechanical properties and durability of concrete made with high-volume fly ash blended cements using a coarse fly ash. Cem Concr Res 31 (2001) 1393-402

20. Mehta P.K., Monteiro P.J.M., Concrete, microstructure, properties and materials. Indian Concr Inst, 1998

21. Kumar S., Kumar R., Mechanical activation of fly ash: Effect on reaction, structure and properties of resulting geopolymer, Ceramics International 37 (2011) 533-541.

22. Felekoglu B., Turkel S., Kalyoncu H., Optimization of fineness to maximize the strength activity of high-calcium ground fly ash - Portland cement composites, Construction and Building Materials 23 (2009) 2053-2061.

23. Mehta PK, Aitcin PC. Principles underlying production of high performance concrete. Cem Concr Aggr 12 (1990) 70-8.

24. Xu Y., Wong Y.L., Poon C.S., Anson N., Impact of high temperature on PFA concrete. Cement and Concrete Research 31 (2001) 1065-1073. 
25. Vilches L.F., Leiva C., Vale J., Fernández-Pereira C., Insulating capacity of fly ash pastes used for passive protection against fire. Cement and Concrete Composites 27 (2005) 776-781.

26. Vilches L.F., Leiva C., Vale J., Fernández-Pereira C., Coal fly ashcontaining sprayed mortar for passive fire protection of steel sections, Materiales de Construcción 55 (2005) 25-37.

27. Leiva C., Vilches L.F., Fernández-Pereira C., Vale J., Influence of the type of ash on the fire resistance characteristics of ash-enriched mortars. Fuel 84 (2005) 1433-1439.

28. Leiva C., Vilches L.F., Querol X., Vale J., Pereira Fernandez, C., Use of zeolitised fly ashes in fire resistant plates. In: Proceedings of the World of Coal Ash: Science, Applications and Sustainability, Covington, KY, United States, 2007.

29. Leiva C., García Arenas C., Vilches L.F., Vale J., Giménez A., Ballesteros J.C., Fernández-Pereira C., Use of FGD gypsum in fire resistant panels. Waste Management 30 (2010) 1123-1129.

\section{VEZA IZMEĐU MIKROSTRUKTURE, FAZNOG SASTAVA I MEHANIČKIH SVOJSTAVA TERMO-IZOLACIONIH VEZIVA NA BAZI OTPADNOG MATERIJALA}

\section{Anja Terzić, Ljubica Pavlović, Jovica Stojanović, Zagorka Radojević}

Konstrukcioni kompoziti - termo-izolaciona i/ili visoko-temperaturna veziva u kojima je leteći pepeo, kao potencijalno štetna materija za okolinu, kombinovan sa običnim $i$ vatrostalnim cementom predstavlja jednu sasvim nоvи mogućnost za reaplikaciju ovog otpadnog materijala. $U$ ovoj studiji, ispitivna su veziva spravljena na bazi dve vrste letećeg pepela dobijenog procesom sagorevanja uglja $i$ dve vrste cementa - obični Portland cement i visoko-aluminatni cement. Promena u mineralnom sastavu kompozita uslovljena povećanjem temperature je analizirana pomoću XRD metode. Mikrostrukturne promene ispitivanih kompozita su utvrđene na osnovu rezultata skening-elektronske mikroskopije (SEM). Makro performanse - mehanička svojstva ispitivanih veziva su povezana sa promenama koje se dešavaju u mikrostrukturi materijala. Ispitivana veziva imaju odlične vrednosti pritisne čvrsoće, a SEM $i$ XRD analiza je ukazala i na potencijalno dobra termo-izolaciona $i$ vatrostalna svojstva ovih materiala.

Ključne reči: Portland cement, visoko-aluminatni cement, leteći pepeo, XRD, mikrostruktura, mehanička svojstva. 